\title{
Evaluation of Cognitive Field Outcomes of Secondary School Physical Education Lesson Teaching Program: Mersin Example
}

\author{
Ortaokul Beden Eğitimi ve Spor Dersi Öğretim \\ Programının Bilişsel Alan Kazanımlarının \\ Değerlendirilmesi: Mersin İli Örneği
}

\author{
Senem Altunbakır ${ }^{1}$ iD https://orcid.org/0000-0001-6139-454X \\ Faculty of Sport Sciences, University of Mersin, Mersin, Turkey
}

\section{Zekai Pehlevan (iD https://orcid.org/0000-0003-4532-2508}

Faculty of Sport Sciences, University of Mersin, Mersin, Turkey

Received: October 25, 2019

Accepted: March 09, 2020

Online Published: March 31, 2019

DOl:10.30655/besad.2020.23

https://doi.org/10.30655/besad.2020.23

\begin{abstract}
This study aims to evaluate cognitive field general goals of secondary school (5th-8th grades) physical education lesson teaching program and the realization level of the dependent outcomes according to different variables. A total 1470 students having education in government and private schools in Mersin City Data was collected with "Secondary School Physical Education Lesson Cognitive Success Test" developed by the researcher. A test battery of 50 items was applied to a group of 100 people to test the credibility of the test, and the test was reduced to 40 items according to article analysis done as a result of the application. KR 20 and 21 credibility coefficients of the success test were found as $K R-20=0.848, K R-21=0,820$. $t$ and $F$ tests were used for the meaningfulness of difference between the groups with descriptive statistics in data analysis. As a result of the analysis, the difference between the groups in terms of gender, school type, scholl area, exam results variables was found meaningful in the outcomes "Explains physical activity and sports concepts related to Healthy Life", "Comprehends our cultural accumulation and values related to physical education" and "Improves thinking skills through physical education and sports" ( $p<0.05)$.
\end{abstract}

Keywords: Physical education and sports, teaching program, program evaluation, cognitive field.

\footnotetext{
${ }^{1}$ Corresponding author: Senem Altunbakır

Mersin Üniversitesi, Spor Bilimleri Fakültesi, Çiftlikköy Yerleşkesi, Yenişehir, Mersin

senemcelik.sca@gmail.com
} 


\section{Öz}

Bu araştırmada; ortaokul (5-8 sınıflar) beden eğitimi ve spor öğretim programının bilişsel alan genel amaçlarının ve bunlara bağlı kazanımların gerçekleşme düzeylerinin farklı değişkenlere göre değerlendirmek amaçlanmıştır. Araştırmanın örneklemini Mersin iline bağlı Yenişehir, Akdeniz, Toroslar. Mezitli ve Tarsus ilçelerinde devlet ve özel okullarda öğrenim gören toplam 1470 öğrenci oluşturmuştur Veriler araştırmacı tarafından geliştirilen "Ortaokul Beden Eğitimi Dersi Bilişsel Başarı Testi" ile toplanmıștır. Testin güvenirliğini test etmek amacılla 100 kişilik gruba 50 maddelik test bataryası uygulanmış, uygulama sonucunda yapılan madde analizine göre test bataryası 40 maddeye indirilerek kullanılmıştır. Başarı Testinin $K R 20$ ve 21 güvenirlik katsayıları $K R-20=0,848, K R-21=0,820$ olarak bulunmuştur. Başarı testi 100 puan üzerinden değerlendirilmiştir. Kazanımlarda yeterlik için ise 70 puan ölçüt alınmıştır. Verilerin analizinde betimsel istatistiklerle birlikte gruplar arası farkın anlamlıı̆ı için $t$ ve $F$ testi kullanılmıştır. Yapılan analizler sonucunda; "Sağlıklı Yaşam ile ilgili fiziksel etkinlik ve spor kavramlarını açıklar", "Beden eğitimi ve sporla ilgili kültürel birikimimizi ve değerlerimizi kavrar" ve "Beden eğitimi ve spor yoluyla düşünme becerilerini geliştirir" çıktılarının gerçekleşme düzeylerinin ortalama puanları çok düşük bulunmuştur.

Anahtar kelimeler: Beden eğitimi ve spor, öğretim programı, program değerlendirme, bilişsel alan

\section{Giriş}

Eğitim niteliğinin geliş̧irilmesi, yenilenmesi eğitim kurumlarının en önemli uğraşlarından birisidir. Örgün eğitim ve yaygın eğitim veren tüm kurumların eğitim faaliyetleri daha önceden hazırlanmış olan plan ve program çerçevesinde yürütülmektedir. Bireylere hangi istendik davranışların nasıl kazandırılacağı eğitim programlarında yer almaktadır. Bu sebeple eğitimin niteliği hazırlanan eğitim programlarına bağlıdır. Uygulanan programların eksiklikleri giderildikçe, programlar yeniden düzenlendikçe eğitimin de niteliğinin artması beklenir. Eğitim programları plansız, gelişigüzel bir şekilde değerlendirilemez. Programların daha etkili bir hale getirilmesi için doğru şekilde kararların alınması ve alınan bu kararların bilimsel çalışmalarla araştııımasını ve uygulamaların değerlendirilmesi gerekir (Erden, 1998). Değerlendirme, program geliştirme faaliyetlerinin en önemli aşamasıdır ve devamlı olacak şekilde bir yönünü oluşturur. Programı değerlendirme sürecindeki alınan sonuçlar veya geri bildirimler programın daha iyi bir şekilde geliştirilmesi için kullanılır (Varış, 1998).

Program değerlendirmenin, genellikle yapılmakta olan programa göre eğitim kaynaklarını kabul etme, değiştirme ya da ortadan kaldırma kararlarının verildiği bilgileri içerdiğini belirtmiştir (Güven ve illeri, 2006). Bulunan değerlendirme sonuçları program gelişstirme uzmanları tarafından programa devam etme, programı gözden geçirme veya programda yeni bir aşamaya geçme konusunda bilgi vermektedir. Aynı zamanda programla ilgili karar vermede, programa yönelik sonuç çıkarmada ve programla ilgili kararları bilgiye dayandırma konusunda program geliştirme uzmanına birçok yetki verir. Kısaca, eğitim sürecinde bireylere istenen yönde davranış kazandırma sürecine doğru ilerlemesini sağlayan öğretim programlarının başlangıçta belirlenen amaçlara ne derecede ulaştığına ilişkin dönüt alabilmek, uygulamada ortaya çıkan eksiklik ve sorunları giderebilmek için programların değerlendirilmesi ve geliştirilmesi gereklidir (Güven ve ileri, 2006).

Eğitim programının başarılı olması için belirlenen hedeflere tüm öğrencilerin ulaşması gerekmektedir, fakat bu her zaman gerçekleşmeyebilir. Bu sebeple eğitim programının uygulanması sonucunda, eksik kalan öğelerin olup olmadığı, varsa bu eksikliklerin neler olduğu, bu eksikliklerin nelerden kaynaklandığını belirlemek ve gerekli düzeltmeleri yapmak sebebiyle programın değerlendirilmesi gerekmektedir. Bu sebeple, değerlendirme yapmanın eğitim programının etkinliği hakkında; veri toplama, verileri ölçülerle karşılaştırıp yorumlama ve programın etkinliliği hakkında karar verme 
basamaklarının oluştuğu söylenebilir (Demirel, 2015). Değerlendirme, karşılaştırma esasına göre ve amacına göre yapılabilir. Buna göre karşılaştırmaya göre yapılan değerlendirme ikiye ayrılmaktadır. Bunlar; norma dayalı değerlendirme ve hedefe dayalı değerlendirme olarak ifade edilir. Norma dayalı yapılan değerlendirmelerde fertlerin birbirleriyle karşılaştırııp seçilmesi söz konusu olduğundan hedefe dayalı yapılan değerlendirmeler program değerlendirmelerde daha tutarlı olmaktadır (Ertürk, 1975). Eğitim programlarının değerlendirilmesi ile ilgili birçok farklı yaklaşım bulunmaktadır. Bu yaklaşımlar arasından günümüze kadar geçerliliği devam eden Hedefe Dayalı Değerlendirme Modeli (Tyler Modeli) Daha sonra geliştirilen birçok program değerlendirme modelinin temel noktası olmuştur. Tyler'ın hedefe dayalı program değerlendirme modeli, Tyler'ın program geliştirme modeline dayalıdır. Öğrencilerin programda belirlenen hedefleri başarma ve hedeflere ulaşma derecesine yönelik olarak geliştirilmiş bir modeldir. Bu modelde programda belirlenen çıktıların değerlendirilmesi, programın amaçlarının gerçekleşip gerçekleşmediğine, amaçlanan hedef ve davranışların ne şekilde tanımlandığı ve bu davranışların nasıl ölçüleceği üzerine bakılır. Bu değerlendirme yaklaşımında kullanılan model ön test ve son test deneysel desendir. Başarılar arasındaki farka bakılarak değerlendirme ile ilgili bir sonuca ulaşılabilir (Demirel, 2015).

Tyler'a göre (Posner, 1992) program değerlendirmede yedi aşamaya yer verilmesi gerekir:

1. Programdaki eğitimin hedeflerini belirlemek,

2. Hedefleri ulaşılmak istenilen özelliklere göre sınıflamak,

3. Hedefleri davranışsal terimler olarak tanımlamak,

4. Hedeflere ulaşılıp ulaşılmadığını gösterecek durumları tanımlamak,

5. Ölçme araçlarını seçme ve geliştirmek,

6. Performansla ilgili verileri toplamak

7. Toplanan verilerle, belirlenen hedefleri karşılaştırmak.

Hedefe dayalı program değerlendirme modelinde bilişsel hedeflere ne derecede ulaşıldığını belirlemek için hedefe dayalı başarı testi, devinişsel beceriler için gözlem formları, duyuşsal hedefler için tutum ölçeklerinden yararlanılır (Demirel, 2015).). Beden eğitimi ve spor dersi öğretim programında bu açıdan belirlenen amaçlarına ne derece ulaşıp ulaşmadığı hakkında bilgi sahibi olunması gereklidir ve belirlenen amaçlara ne derece ulaşıp ulaşmadığı hakkında bilgi sahibi olunması, programın ne derecede etkili olduğunu belirlemek için de gereklidir. Bu araştırmanın genel amacı; ortaokul beden eğitimi ve spor öğretim programının bilişsel alan çıktılarının ve bu çıktılara bağlı kazanımların gerçekleşme düzeylerini belirlemektir. Beden eğitimi ve spor öğretim programında dokuz adet öğrenme çıktısı bulunmaktadır. Bu çıktıların üç tanesi bilişsel alandan oluşur. Bu araştırmada aşağıda verilen bilişsel alan çıktıların gerçekleşme düzeyleri incelenecektir. Bu çıtılar;

1. Sağlıklı yaşamla ilgili fiziksel etkinlik ve spor kavramlarını ve ilkelerini açıklar, çıktısının gerçekleşme düzeyi nedir?

2. Beden eğitimi ve sporla ilgili kültürel birikimimizi ve değerlerimizi kavrar, çıktısının gerçekleşme düzeyi nedir?

3. Beden eğitimi ve spor yoluyla düşünme becerilerini geliştirir, çıktısının gerçekleşme düzeyi nedir?

\section{Yöntem}

\section{Araştırma Modeli}

Bu araştırmada nicel araştırma türlerinden betimsel araştırma (tarama/survey) kullanılmıştır. Betimsel araştırma, yaşananların, hali hazırda var olanların neler olduğunun betimlenip açıklanarak ortaya konulması amaçlanmaktadır. Genel tarama modelleri, çok sayıda elemanı bulunan bir evrende, evren hakkında genel bir yargıya varmak amacı ile evrenin tümü ya da ondan alınacak bir grup örnek ya da örneklem üzerinde yapılan tarama düzenlemeleridir (Karasar, 2015). 


\section{Evren ve Örneklem}

Araştırmanın birim evrenini 2017-2018 eğitim öğretim yılında Mersin il merkezinde okuyan 8. sınıf öğrencileri oluşturmaktadır. Araştırmadaki evreni oluşturan öğrenci sayıları Mersin Milli Eğitim Müdürlüğünden alınmış olup toplam evren sayısı 19.836'dır. Araştırmanın örneklemini oluşturan öğrenci sayıları ise Mersin iline bağlı Yenişehir, Akdeniz, Toroslar, Mezitli ve Tarsus ilçelerinde devlet ve özel okullarda öğrenim gören toplam 1500 öğrenci oluşturmuştur (Tablo 1). Örneklem grubu tabakalı örneklem yöntemiyle basit seçkisiz yolla seçilmiştir.

Tablo 1. Araştırmaya Katılan Örneklem Sayısı

\begin{tabular}{ccccc}
\hline Bölge & \multicolumn{2}{c}{ Evren } & \multicolumn{2}{c}{ Örneklem (n ve \%) } \\
& Okul sayısı & Öğrenci sayı & Okul sayısı & Öğrenci sayısı \\
\hline Toroslar & 40 & 4330 & $4(10,0)$ & $280(6,5)$ \\
Mezitli & 25 & 2085 & $4(16,0)$ & $280(13,4)$ \\
Yenişehir & 37 & 3576 & $6(16,2)$ & $350(9,8)$ \\
Tarsus & 45 & 5216 & $4(8,9)$ & $280(5,4)$ \\
Akdeniz & 44 & 4629 & $4(9,1)$ & $280(6,0)$ \\
Toplam & 191 & 19.836 & $22(11,5)$ & $1470(7,4)$ \\
\hline
\end{tabular}

\section{Veri Toplama Aracı ve İşlem Yolu}

Bu araştırmaya yönelik bir ölçme aracı bulunmadığından, araştırmacı tarafından 40 maddelik "Ortaokul Beden Eğitimi Dersi Bilişsel Başarı Testi" geliştirilmiştir. Beden eğitimi dersi bilişsel başarı testinin hazırlık aşamalarında öncelikli olarak Beden eğitimi ve spor dersi öğretim programı incelenmiştir. Incelenen programda Beden eğitimi ve spor dersine ait 9 çıktının bulunduğu ve bu çıktılar içerisinde üç çıktının bilişsel alan çıktısı olduğu belirlendi. Bu çıktılar; Sağlıklı yaşamla ilgili fiziksel etkinlik ve spor kavramlarını ve ilkelerini açılar. Beden eğitimi ve sporla ilgili kültürel birikimimizi ve değerlerimizi kavrar, Beden eğitimi ve spor yoluyla düşünme becerilerini geliştirir olarak sıralanabilir.

Bilişsel çıktılara ait kazanımları belirlemek amacıyla programda yer alan 5, 6, 7 ve 8.sınıfların kazanımları incelenerek toplam bilişsel kazanımlar ve kazanımların sınıflara göre dağılımları belirlenmişstir. Bilişsel çıktılar ve bu çıktıların hangi kazanımlarla ilişkili olduğunu gösteren 5, 6, 7 ve 8. Sınıf programlarına ait belirtke tabloları oluşturulmuştur. Belirtke tablolarına ve programda belirtilen kazanım öğretim öneri açıklamalarına uygun olarak sorular yazılarak, soru havuzu oluşturuldu. Soru havuzundan sorular; uzman görüşleri, öğretmen ve öğrenci görüşleri doğrultusunda seçilerek "Ortaokul Beden Eğitimi Dersi Bilişsel Başarı Testi" 50 soruya indirilmiştir. Seçilen 50 soruluk "Ortaokul Beden Eğitimi Dersi Bilişsel Başarı Testi" 8. sınıfta öğrenim gören 100 öğrenciye uygulandı. Uygulanan testin her maddesinin ayırt ediciliği ve madde güçlük analizleri yapıldı Yapılan bu analiz sonucunda 10 maddenin uygun olmadığı belirlenmiş ve test bataryasından çıkarılmışı Seçilen 40 maddelik Ortaokul beden eğitimi dersi bilişsel kazanım test bataryasının tekrar madde analizi yapılmıştır. Testin Ortalama güçlük indeksi $=0,586$ ve Ortalama ayırt edicilik $=0.422$ bulunmuştur. KR-20 $(0,848)$ KR-21(0,820), bakılarak testlerin uygun olduğu belirlenmiş ve Ortaokul beden eğitimi dersi bilişsel başarı testi hazır hale getirilmiştir (Tablo 2).

\section{Verilerin Toplanması}

Çalışma için gerekli izinler (valilik onayı, milli eğitim izin yazısı ve etik kurul onayı) alındıktan sonra Mayıs 2017 - 15 Haziran 2017 tarihleri arasında 8. Sınıfta eğitim gören öğrencilere. 40 maddeden oluşan, 4 seçenekli, çoktan seçmeli sorulardan oluşan Ortaokul beden eğitimi dersi bilişsel başarı testi 
uygulanmıştır. Araştırmaya katılmak isteyen gönüllü öğrencilerden veriler toplanmıştır. Testi cevaplamak için öğrencilere toplam 40 dakika zaman verilmiştir.

Tablo 2. Ortaokul Beden Eğitimi Dersi Bilişsel Başarı Testi Analizi

\begin{tabular}{|c|c|c|c|c|c|c|c|c|}
\hline Madde & $\begin{array}{l}\text { Doğru } \\
\text { Sayısı }\end{array}$ & $\begin{array}{l}\text { Madde } \\
\text { Güçlük }\end{array}$ & $\begin{array}{c}\text { Madde } \\
\text { Ayırt }\end{array}$ & $\begin{array}{l}\text { Üst Grup } \\
(\% 27)\end{array}$ & $p$ & $\begin{array}{l}\text { Alt Grup } \\
(\% 27)\end{array}$ & $\begin{array}{c}\text { Çift Seri } \\
\text { Kor. }\end{array}$ & $\begin{array}{c}\text { Düz Nokta } \\
\text { Kor. }\end{array}$ \\
\hline $1 \#$ & 91 & 0.90 & 0.00 & $29(0,97)$ & $1,00^{*}$ & $27(0,96)$ & $-0,03$ & $-0,07$ \\
\hline 2 & 81 & 0.80 & 0.36 & $28(0,93)$ & .001 & $16(0,57)$ & 0,43 & 0,39 \\
\hline 3 & 50 & 0.50 & 0.24 & $19(0,63)$ & $.058^{*}$ & $11(0,39)$ & 0,27 & 0,21 \\
\hline 4 & 82 & 0.81 & 0.32 & $30(1,00)$ & ,010 & $19(0,68)$ & 0,36 & 0,31 \\
\hline 5 & 73 & 0.72 & 0.40 & $27(0,90)$ &, 006 & $14(0,50)$ & 0,30 & 0,24 \\
\hline 6 & 62 & 0.61 & 0.51 & $26(0,87)$ & .001 & $10(0,36)$ & 0,39 & 0,34 \\
\hline 7 & 95 & 0.94 & 0.18 & $30(1,00)$ & ,019 & $23(0,82)$ & 0,27 & 0,24 \\
\hline 8 & 87 & 0.86 & 0.36 & $29(0,97)$ & .002 & $17(0,61)$ & 0,41 & 0,37 \\
\hline $9 \#$ & 18 & 0.18 & 0.16 & $8(0,27)$ &, $094^{*}$ & $3(0,11)$ & 0,17 & 0,12 \\
\hline $10 \#$ & 84 & 0.83 & 0.12 & $26(0,87)$ & $.167^{\star}$ & $21(0,75)$ & 0,16 & 0,11 \\
\hline 11 & 80 & 0.79 & 0.47 & $28(0,93)$ &, 000 & $13(0,46)$ & 0,54 & 0,50 \\
\hline 12 & 82 & 0.81 & 0.29 & $29(0,97)$ & .036 & $19(0,68)$ & 0,27 & 0,22 \\
\hline $13 \#$ & 23 & 0.23 & -0.11 & $3(0,10)$ & $.493^{*}$ & $6(0,21)$ & $-0,02$ & $-0,08$ \\
\hline 14 & 72 & 0.71 & 0.54 & $29(0,97)$ &, 000 & $12(0,43)$ & 0,39 & 0,34 \\
\hline 15 & 70 & 0.69 & 0.30 & $26(0,87)$ & .034 & $16(0,57)$ & 0,22 & 0,16 \\
\hline 16 & 77 & 0.76 & 0.29 & $28(0,93)$ & .036 & $18(0,64)$ & 0,24 & 0,19 \\
\hline 17 & 79 & 0.78 & 0.36 & $29(0,97)$ & .001 & $17(0,61)$ & 0,39 & 0,34 \\
\hline 18 & 89 & 0.88 & 0.29 & $29(0,97)$ & .004 & $19(0,68)$ & 0,52 & 0,49 \\
\hline 19 & 82 & 0.81 & 0.32 & $29(0,97)$ &, 000 & $18(0,64)$ & 0,41 & 0,36 \\
\hline 20 & 78 & 0.77 & 0.36 & $27(0,90)$ &, 006 & $15(0,54)$ & 0,44 & 0,40 \\
\hline 21 & 83 & 0.82 & 0.43 & $30(1,00)$ &, 000 & $16(0,57)$ & 0,44 & 0,39 \\
\hline 22 & 79 & 0.78 & 0.54 & $30(1,00)$ &, 000 & $13(0,46)$ & 0,62 & 0,59 \\
\hline 23 & 66 & 0.65 & 0.30 & $23(0,77)$ & .047 & $13(0,46)$ & 0,30 & 0,24 \\
\hline 24 & 63 & 0.62 & 0.34 & $23(0,77)$ &, 013 & $12(0,43)$ & 0,37 & 0,31 \\
\hline 25 & 56 & 0.55 & 0.37 & $23(0,77)$ & .027 & $11(0,39)$ & 0,26 & 0,20 \\
\hline 26 & 82 & 0.81 & 0.36 & $29(0,97)$ & .002 & $17(0,61)$ & 0,48 & 0,44 \\
\hline 27 & 48 & 0.48 & 0.52 & $22(0,73)$ &, 000 & $6(0,21)$ & 0,41 & 0,35 \\
\hline 28 & 76 & 0.75 & 0.47 & $27(0,90)$ & ,000 & $12(0,43)$ & 0,56 & 0,52 \\
\hline 29 & 40 & 0.40 & 0.46 & $18(0,60)$ &, 000 & $4(0,14)$ & 0,36 & 0,30 \\
\hline 30 & 61 & 0.60 & 0.58 & $26(0,87)$ & .002 & $8(0,29)$ & 0,40 & 0,34 \\
\hline 31 & 82 & 0.81 & 0.29 & 28(0,93) &, 000 & $18(0,64)$ & 0,37 & 0,33 \\
\hline 32 & 73 & 0.72 & 0.54 & 28(0,93) &, 000 & $11(0,39)$ & 0,57 & 0,53 \\
\hline 33 & 64 & 0.63 & 0.69 & $27(0,90)$ &, 000 & $6(0,21)$ & 0,61 & 0,57 \\
\hline 34 & 74 & 0.73 & 0.82 & $30(1,00)$ & ,000 & $5(0,18)$ & 0,72 & 0,69 \\
\hline 35 & 71 & 0.70 & 0.61 & 28(0,93) &, 000 & $9(0,32)$ & 0,55 & 0,51 \\
\hline 36 & 44 & 0.44 & 0.35 & $18(0,60)$ & .002 & $7(0,25)$ & 0,32 & 0,26 \\
\hline 37 & 71 & 0.70 & 0.50 & 28(0,93) &, 000 & $12(0,43)$ & 0,48 & 0,44 \\
\hline 38 & 66 & 0.65 & 0.55 & $26(0,87)$ &, 000 & $9(0,32)$ & 0,50 & 0,45 \\
\hline 39 & 45 & 0.45 & 0.11 & $15(0,50)$ &, $419^{*}$ & $11(0,39)$ & 0,12 & 0,05 \\
\hline 40 & 50 & 0.50 & 0.56 & $20(0,67)$ &, 000 & $3(0,11)$ & 0,45 & 0,40 \\
\hline 41 & 59 & 0.58 & 0.55 & $23(0,77)$ & ,000 & $6(0,21)$ & 0,44 & 0,38 \\
\hline
\end{tabular}




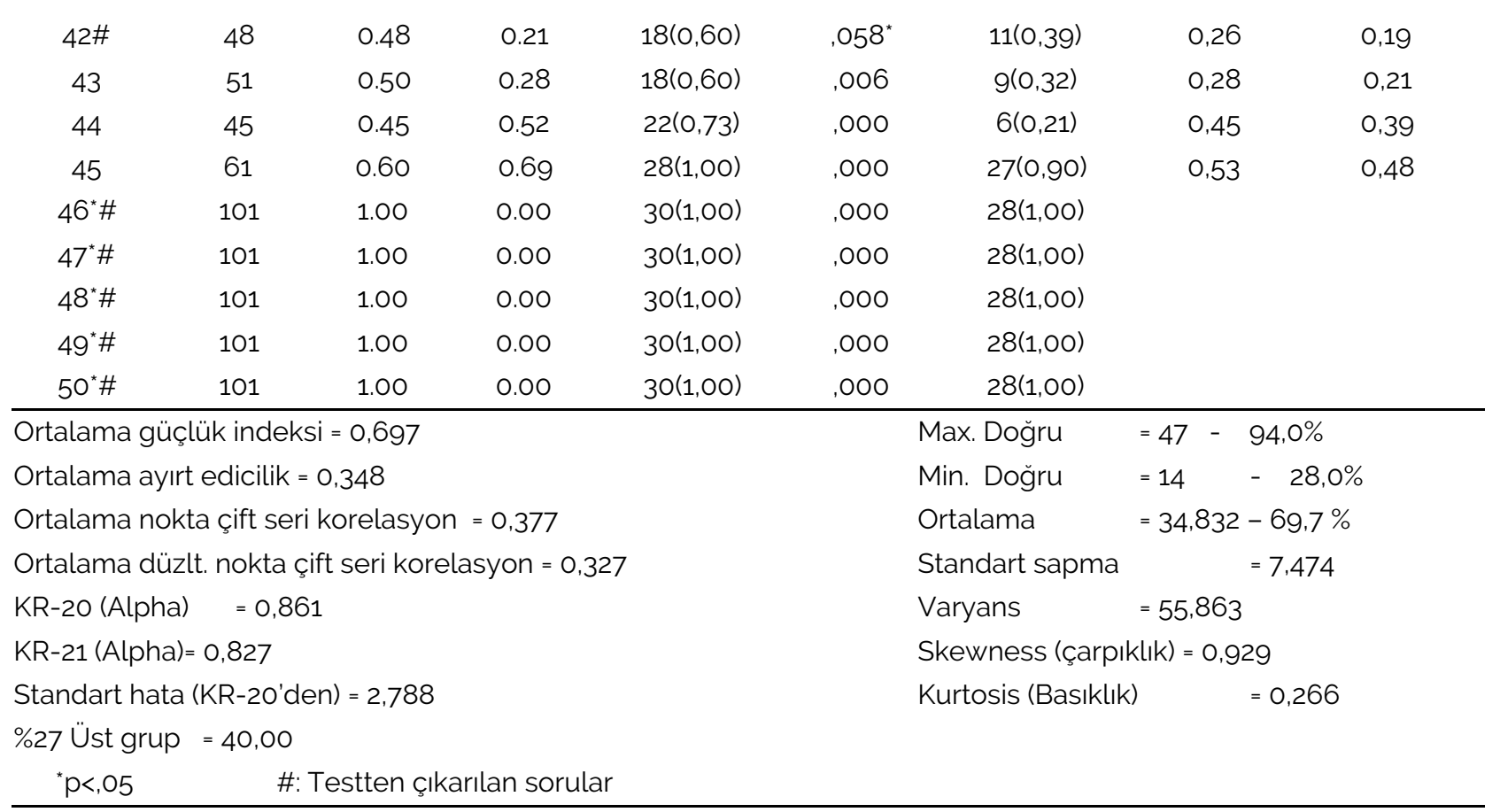

\section{Verilerin Analizi}

Ortaokul Beden Eğitimi Dersi Bilişsel Alan Testi 1500 öğrenciye uygulandıktan sonra cevaplama işlemlerinin uygun olup olmadığı kontrol edilmiştir yapılan kontroller sonucunda; tüm sorulara aynı şıkları işaretleyen, testleri işaretlemeden boş veren 30 öğrencinin testi geçersiz sayılmış 1470 tanesi geçerli test sonucuna ulaşılmıştır. Ölçme sonucunda elde edilen verilerin analizinde betimsel istatistiklerle birlikte gruplar arası farkın anlamlıı̆ı için t ve F testi kullanılmıştır.

\section{Bulgular}

Ortaokul beden eğitimi ve spor öğretim programında mevcut olan üç çıktı ve bu üç çıktıdan alınan toplam puanlara dayalı çıkarımlar yapılmıştır. Ortaokul beden eğitimi öğretim programın bilişsel çıktılarından alınan toplam puan analizi incelendiğinde; Sağlıklı Yaşam ile ilgili fiziksel etkinlik ve spor kavramlarını açıklar, çıkısının toplam puan ortalaması (=61,6; Ss=24,4) bulunmuştur. Alt kazanımlar incelendiğinde; "Spor dallarına özgü kavramları açıklar" kazanımı (=85,6;Ss=35,1) ve "Katıldığı planlı spor etkinliklerinin, fiziksel uygunluğuna etkilerini değerlendirir" ( $=75,6 ; S s=35,6)$ kazanımlarında yüksek düzeyde puanlar alındığı, "Fiziksel etkinliklerde ilk yardımın genel amaçları ve uygulamalarını bilir" $(=40,8 ;$ Ss=36,9) alt kazanımından alınan ortalama puanın çok düşük düzeyde olduğu gözlemlenmiştir. Belirtilen alt kazanımlar dışında diğer kazanımlarda yüksek puanlar alınmadığı bulunmuştur.

Tablo 4 incelendiğinde; "Beden eğitimi ve sporla ilgili kültürel birikimimizi ve değerlerimizi kavrar" çıktısının toplam puan ortalaması (=58,9;Ss=31,7) düşük düzeyde bulunmuştur. Bu çıktıyı oluşturan tüm alt kazanımlara ait ortalama puanlarda düşük düzeyde puanlar alındığı sonucu bulunmuştur. Tablo 5'de "Beden eğitimi ve spor yoluyla düşünme becerilerini geliştirir", çıktısı ortalama toplam puanı (=65,1;Ss=24,9) düşük düzeyde bulunduğu sonucu ortaya çıkmıştır. Alt kazanımlarda bulunan, "Fiziksel etkinlik düzeyini korumak için kullandığı motivasyon yöntemlerinin etkilerini kavrar" $(=80,1 ; \mathrm{Ss}=40,0)$, "Sporlara hazırlayıcı oyun ve etkinliklerde kendi performansını analiz eder"(=74,6;Ss=37,3), "Sporlara hazırlayıcı oyun ve etkinliklerde karşılaştığı problemlerle eşle ve grupla çözümler üretir" $(=74,1 ; \mathrm{Ss}=43,8)$ "Katıldığı sporlarda karşılaştığı spor sakatlıklarından korunma yöntemlerini bilir" $(=70,5 ;$ Ss $=45,6)$, "Fiziksel etkinlikler ve spor konusunda medyada çıkan haberleri analiz eder" 
$(=70,0 ;$ Ss=33,2) kazanımlarında, diğer alt kazanımlarından daha yüksek puanların alındığı sonucu bulunmuştur.

Tablo 3. Sağlıklı Yaşam ile ilgili Fiziksel Etkinlik ve Spor Kavramlarını Açıklar Çıktısı Toplam puan analizi ( $\mathrm{N}=1470)$

\begin{tabular}{|c|c|c|c|c|}
\hline $\begin{array}{l}\text { Kazanımlar } \\
\text { Toplam }\end{array}$ & $\begin{array}{c}\mathrm{X} \\
61,6\end{array}$ & $\begin{array}{c}\text { Ss } \\
24,4\end{array}$ & $\begin{array}{l}\text { Çarpıklık } \\
-, 307\end{array}$ & $\begin{array}{c}\text { Basıklık } \\
-1,161\end{array}$ \\
\hline Spor dallarına özgü kavramları açıklar & 85,6 & 35,1 & $-2,028$ & 2,114 \\
\hline Spor dallarına ait oyun kurallarını bilir & 55,6 & 32,3 &,- 120 & -.991 \\
\hline $\begin{array}{l}\text { Katıldığı planlı spor etkinliklerinin, fiziksel uygunluğuna } \\
\text { etkilerini değerlendirir }\end{array}$ & 75,6 & 35,6 & $-1,113$ &,- 178 \\
\hline $\begin{array}{l}\text { Fiziksel etkinlikler sırasında aldığı besin desteklerinin } \\
\text { yarar ve zararlarını açıklar }\end{array}$ & 64,0 & 37,0 & -.500 & $-1,039$ \\
\hline $\begin{array}{l}\text { Takip ettiği fiziksel etkinlik programının, fiziksel } \\
\text { uygunluğa etkilerini açıklar }\end{array}$ & 65.5 & 37,6 & -.578 & $-1,028$ \\
\hline $\begin{array}{l}\text { Fiziksel etkinliklerde uygulayabileceği kişisel beslenme } \\
\text { programı hazırlar. }\end{array}$ & 60,9 & 39,6 &,- 407 & $-1,294$ \\
\hline $\begin{array}{l}\text { Sporlara hazırlayıcı oyun ve etkinliklerde kullandığı } \\
\text { hareket kavramlarını açıklar }\end{array}$ & 61,6 & 34.7 & -.348 & -.911 \\
\hline $\begin{array}{l}\text { Fiziksel etkinlik sırasında enerji veren ve sağlığını } \\
\text { koruyan temel besin öğelerini açıklar }\end{array}$ & 43,9 & 49,6 &, 244 & $-1,943$ \\
\hline $\begin{array}{l}\text { Fiziksel etkinlikler sırasında karşılaştığı sağlık sorunlarını } \\
\text { ve bu sorunlardan korunma yöntemlerini bilir. }\end{array}$ & 57,1 & 49,5 &,- 286 & $-1,921$ \\
\hline $\begin{array}{l}\text { Oyun ve etkinliklerde kullandığı temel hareket } \\
\text { kavramlarını açıklar. }\end{array}$ & 63.5 & 48,1 & -.563 & $-1,685$ \\
\hline $\begin{array}{l}\text { Oyun ve etkinliklerde beceri gelişimi için kendi } \\
\text { kontrolünde olan faktörleri bilir }\end{array}$ & 61,6 & 48,6 &,- 479 & $-1,773$ \\
\hline $\begin{array}{l}\text { Katıldığı fiziksel etkinliklerin, fiziksel uygunluğa etkilerini } \\
\text { açıklar. }\end{array}$ & 65.9 & 39,2 &,- 625 & $-1,106$ \\
\hline $\begin{array}{l}\text { Fiziksel etkinliklerde ne zaman ve nasıl beslenmesi } \\
\text { gerektiğini açıklar. }\end{array}$ & 62,0 & 48,5 &,- 497 & $-1,756$ \\
\hline $\begin{array}{l}\text { Fiziksel etkinliklerde kendisinin ve başkalarının sağlık ve } \\
\text { güvenliğine etki eden durumları açıklar }\end{array}$ & 59,8 & 49,0 &,- 400 & $-1,843$ \\
\hline $\begin{array}{l}\text { Fiziksel etkinliklerde ilk yardımın genel amaçları ve } \\
\text { uygulamalarını bilir }\end{array}$ & 40,8 & 36,9 & .306 & $-1,118$ \\
\hline
\end{tabular}

Tablo 4. Beden Eğitimi ve Sporla İlgili Kültürel Birikimimizi ve Değerlerimizi Kavrar Çıktısı Toplam Puan Analizi ( $\mathrm{N}=1470)$

\begin{tabular}{lcccc}
\hline \multicolumn{1}{c}{$\begin{array}{c}\text { Kazanımlar } \\
\text { Toplam }\end{array}$} & $\mathbf{X}$ & Ss & Çarpıklık & Basıklık \\
& $\mathbf{5 8 , 9}$ & $\mathbf{3 1 , 7}$ & $\mathbf{- , 3 0 7}$ & $\mathbf{- 1 , 0 1 8}$ \\
\hline Atatürk'ün spora ve sporcuya verdiği önemi inceleyerek & 69,7 & 46,0 &,- 856 & $-1,269$ \\
çıkarımlarda bulunur. & & & & \\
Yakın çevresine ait halk danslarını bilir. & 61,1 & 48,8 &,- 455 & $-1,795$ \\
Geleneksel çocuk oyunlarını tanır & 50,0 & 50,0 &,- 000 & $-2,003$ \\
Olimpik kavramları bilir & 54,9 & 49,8 &,- 197 & $-1,964$ \\
\hline
\end{tabular}


Tablo 5. Beden eğitimi ve Spor Yoluyla Düşünme Becerilerini Geliştirir Çıktısı Toplam Puan Analizi $(\mathrm{N}=1470)$

\begin{tabular}{|c|c|c|c|c|}
\hline $\begin{array}{l}\text { Kazanım } \\
\text { Toplam }\end{array}$ & $\begin{array}{c}X \\
65,1\end{array}$ & $\begin{array}{c}\text { Ss } \\
24,9\end{array}$ & $\begin{array}{l}\text { Çarpıklık } \\
-, 628\end{array}$ & $\begin{array}{c}\text { Basıklık } \\
-, 582\end{array}$ \\
\hline Spor becerilerinin hareket evrelerini analiz eder & 45,1 & 49,8 & 197 & $-1,964$ \\
\hline $\begin{array}{l}\text { Fiziksel etkinlik düzeyini korumak için kullandığı } \\
\text { motivasyon yöntemlerinin etkilerini kavrar }\end{array}$ & 80,1 & 40,0 & $-1,507$ & ,271 \\
\hline $\begin{array}{l}\text { Sporlara hazırlayıcı oyun ve etkinliklerde kendi } \\
\text { performansını analiz eder }\end{array}$ & 74,6 & 37.3 & $-1,081$ &.,- 370 \\
\hline $\begin{array}{l}\text { Sporlara hazırlayıcı oyun ve etkinliklerde karşılaştığı } \\
\text { problemlerle esle ve grupla çözümler üretir }\end{array}$ & 74,1 & 43,8 & $-1,100$ & -.790 \\
\hline $\begin{array}{l}\text { Sporlara hazırlayıcı oyun ve etkinliklerde kendisinin ve } \\
\text { arkadaşlarının performansını değerlendirir }\end{array}$ & 39,5 & 48,9 & .429 & $-1,818$ \\
\hline Oyun ve etkinliklerde işbirliğinin önemini kavrar & 66,5 & 47,2 &,- 698 & $-1,515$ \\
\hline $\begin{array}{l}\text { Oyun ve etkinliklerde kendisinin ve arkadaşlarının } \\
\text { performanslarını değerlendirir }\end{array}$ & 65.7 & 47.5 &,- 663 & $-1,563$ \\
\hline $\begin{array}{l}\text { Katıldığı sporlarda karşılaştığı spor sakatıklarından } \\
\text { korunma yöntemlerini bilir. }\end{array}$ & 70,5 & 45,6 &,- 902 & $-1,187$ \\
\hline $\begin{array}{l}\text { Fiziksel etkinlikler ve spor konusunda medyada çıkan } \\
\text { haberleri analiz eder }\end{array}$ & 70,0 & 33,2 &,- 741 &,- 656 \\
\hline
\end{tabular}

\section{Bulgular}

Beden eğitimi ve spor dersi bilişsel çıktılarından olan "Sağlıkı yaşam ile ilgili fiziksel etkinlik ve spor kavramlarını açıklar" çıktısını değerlendirildiğinde; öğrencilerin çıktıyı oluşturan kazanımlarda yüksek düzeyde puanlar almadığı bulunmuştur. Çıktıyı oluşturan kazanımlar incelendiğinde sadece "Spor dallarına özgü kavramları açıklar" kazanımı ve "Katıldığı planlı spor etkinliklerinin, fiziksel uygunluğuna etkilerini değerlendirir" kazanım sonuçlarında ortalama puanın yüksek bulunmuştur. "Beden eğitimi ve sporla ilgili kültürel birikimimizi ve değerlerimizi kavrar" çıktısının sonuçlarına göre öğrencilerin çıktının ortalama puanı ve çıktıyı oluşturan kazanımların ortalama toplam incelendiğinde hiçbir kazanımda yüksek düzeyde puanlar alınmamıştır.

"Beden eğitimi ve spor yoluyla düşünme becerilerini geliştirir" çıktısında ve çıktıyı oluşturan kazanımlar incelendiğinde diğer çıtılara göre ortalama toplam puan daha yüksek bulunmuştur. "Fiziksel etkinlik düzeyini korumak için kullandığı motivasyon yöntemlerinin etkilerini kavrar", "Sporlara hazırlayıcı oyun ve etkinliklerde karşılaştığı problemlerle eşle ve grupla çözümler üretir", "Katılığı sporlarda karşılaştığı spor sakatlıklarından koruma yöntemlerini bilir", "Fiziksel etkinlikler ve spor konusunda medyada çıkan haberleri analiz eder" kazanımlarda öğrenmelerin daha yüksek düzeyde gerçekleştiği diğer alt kazanımlarında daha düşük ortalama puanlar alınmış olduğu söylenebilir. Programda belirlenen çıktıların değerlendirilmesi, programın amaçlarının gerçekleşip gerçekleşmediğine, amaçlanan hedef ve davranışların ne şekilde tanımlanacağı ve bu davranışların ölçülme sonuçlarına bakıır ve Eğitim programının uygulanması sonucunda, eksik kalan ögelerin olup olmadığı, varsa bu eksikliklerin neler olduğu, bu eksikliklerin nelerden kaynaklandığı belirlemek ve gerekli düzeltmeleri yapmak sebebiyle programın değerlendirilmesi gerekmektedir. Bu sebeple değerlendirme yapmanın eğitim programının etkinliği hakkında; veri toplama, verileri ölçülerle karşılaştırıp yorumlama ve programın etkinliliği hakkında karar verme basamaklarının oluştuğu söylenebilir (Demirel, 2011). Yaptığımız araştırma sonucu ortaokul beden eğitimi ve spor dersi öğretim programının bilişsel çıktılarının ve bu çıktılara ulaşmak için belirlenen kazanımlarda alınan puanların 
düşük düzeyde olması. Öğrencilerin beden eğitimi ve spor dersi öğretim programını tam öğrenmeden mezun olduğunu göstermektedir. Beden eğitimi ve spor dersi bilişsel kazanımların değerlendirmesi öğretim programını geliştirme açısından bize çok önemli geri dönütler sağlayabilir. Programın başarıya ulaşmamasının birçok faktör ve sebebi bulunabilir. Programda belirtilen Beden Eğitimi dersinin uygulanmasına ilişkin açıklamalar incelendiğinde; çıktıların gerçekleşmesi için programda dersler yapılırken; okulların durumlarına özgü uyarlamalar yapııması, farklı öğretim yaklaşım ve stratejilerine önem verilmesi, kazanımların diğer derslerle ve yaşamla ilişkilendirilmesi, kişisel (öğrenciler, öğretmenler, okul velileri, okul yöneticileri, antrenörler vb.) ve kurumsal paydaşların(okul il spor müdürlükleri, kulüp, spor federasyonları, belediyeler, il sağlık müdürlükleri vb.) işbirliği içinde olması, özel intiyacı olan öğrencilere uygun eğitim verilmesi, eğitim teknolojileri (kitaplar, medya, bilgisayar destekli vb.) kullanılması ve ölçme ve değerlendirme yaparken süreç odaklı ve bireysel değerlendirmeler yapılması gerektiği belirtilmiştir. Programda bilişsel çıktılarının başarı ile sonuçlanmaması; okullarda verilen eğitimin programın uygulanmasında sorunlar olduğunu ya da çıktıların ve çıktıları oluşturan kazanımların oluşturulmasında sorunlar olduğunu göstermektedir. Şirinkan ve Gündoğdu (2011), beden eğitimi ve spor öğretim programı hedef ve kazanımlarının içerik, metot, teknik ve değerlendirme süreci bakımından hedeflenen ile mevcut durum arasında farklııkları olduğu; eğitim ve öğretim programı ile amacın birbirine uymadığı; hedef ve kazanımların önemli olduğunun vurgulanmasına rağmen, öğrenciler tarafından yeterince sağlanamadığı sonucuna ulaşmışlardır. Gülüm ve arkadaşları (2011) araştırmasında; kazanımlar ile ilgili ifadeler incelendiğinde kullanılan bazı ifadelerin uygulamada esnasında zorluklar yaşanmasına sebep olabileceğini belirtmişlerdir. Erdoğdu ve Öçalan (2010) araştırmalarında;2. kademe Beden Eğitimi Dersi Öğretim Programının uygulanabilirlik düzeyi öğretmenler açısından; programının genel amaçları, kazanımlar, öğrenme-öğretme süreci alt boyutlarında "kısmen" ve ölçme-değerlendirme alt boyutlarında "az" olarak görüldüğü anlaşılmaktadır. Taşmektepligil, Yılmaz, İmamoğlu ve Kılcıgil (2006) haftalık beden eğitimi ders süresinin dersle ilgili genel ve özel amaçlara ulaşabilmek için yeterli olmadığı, öğretmenlerin planları hazırlarken müfredatın tamamına değil, daha çok bildikleri konulara öncelik verdikleri, okullarda yeterli tesis ve malzeme bulunmadığı ve sportif faaliyetlere okul idarelerinin yeterli desteği vermediği belirlenmiştir. Mamak (2012), araştırması kapsamındaki okullarda beden eğitimi ve spor derslerinde okulun tesis durumu, öğrencilerin dersin önemini kavrama, ders saatlerinin yetersizliği, okul idaresi ve branş öğretmenlerinin beden eğitimi öğretmenlerine desteği konusunda yetersizlikler olduğu tespit edilmiştir.

Eğitimin hedefleri ile felsefe birbirinden ayrılmayan iki önemli unsurdur. Bir ülkenin insanlarının hayat görüşleri, yaşam şekilleri, inançları, değerleri ve istekleri eğitimin hedeflerine yansımaktadır. Hedefler seçilirken ve bu hedefler arasında tutarlılı sağlanmasında eğitim felsefesi önemli bir rol sağlamaktadır. Felsefe, eğitim, eğitim felsefesi üçlüsü bir arada iken incelendiğinde farklı sistemlere göre eğitim akımlarının gerçekleştiğini görmekteyiz ve insanlar bu eğitim akımlarına göre eğitim programları geliştirmekte ve değişik programlar denenmektedirler (Demirhan, 1997; Oliva 1997). Felsefi yaklaşımların hedefleri farklı olduğundan; ülkedeki öğretmen ve insan yetiştirme şekilleri farklıık göstermektedir. Bu durum ülkelerin eğitim politikaları ile ilgilidir. Bir ülkedeki eğitim sistemleri bir bütündür ve sistem alt sistemleri şekillendirir. Beden eğitimi ve spor dersi de eğitimin bir alt sistemidir. Bu alt sistemin temel öğeleri öğrenciler, öğretmenler ve eğitim programlarıdır (Ertürk, 2015). Bu sebepten dolayı beden eğitimi ve spor öğretim programının eğitimimizdeki akımları, yenilikleri göz önünde bulundurarak eğitim hedefleri oluşturulurken çağımıza uygun, gerçekleşebilecek olanakta hedefler konulmasına dikkat edilmelidir. Bu araştırmada çalışmaya katılan öğrencilere uygulanan Ortaokul beden eğitimi dersi bilişsel başarı testi sonucunda "Sağlıklı yaşam ile ilgili fiziksel etkinlik ve spor kavramlarını açıklar", çıktısında, Beden eğitimi ve sporla ilgili kültürel birikimimizi ve değerlerimizi kavrar" çıktısında ve Beden eğitimi ve spor yoluyla düşünme becerilerini geliştirir" çıktısında yeterli düzeyde öğrenme gerçekleşmediği söylenebilir. 


\section{Sonuç}

Ortaokul beden eğitimi ve spor öğretim programı bilişsel çıtıtları ve bu çıktıyı oluşturan kazanımlarda ile ilgili öğretim programının geliştirilmesinde yetkili olan karar verici ve yöneticiler tarafından öğretim programı tekrar gözden geçirilmelidir. Öncelikle bilişsel çıktılar ve bu çıktıyı oluşturan alt kazanımlar kontrol edilmeli, düzeltilmeli, gerekirse başarı sağlanamayan kazanımlar çıkarılmalı ya da yeniden oluşturulmalıdır. Değerlendirme sonuçlarına göre program geri dönütlerle daha uygulanabilecek şekilde geliştirilmelidir. Türkiye'de okulların fiziki koşulları, imkân ve olanakları, malzeme tesis yeterliliği, iklim koşulları vb durumlar göz önünde bulundurularak programı oluşturan kazanımlar bunlara göre yeniden oluşturulmalıdır. Programda kazanımlar genel olarak verilmiştir araştırma yapılırken kazanımların bilişsel, psikomotor ve duyuşsal olarak ayrımasının programın anlaşıır olmasını arttıracağı için yeniden düzenlenmesini, Öğretim programındaki bu kazanım-çıktı ilişkileri düzenlemelerinin daha anlaşıır şekilde yapılması önerilmektedir. Bu alanda çalışan araştırmacıların öğretim programının değerlendirilmesine yönelik farklı çalışmalar ile alana katkı sağlaması, Tüm çıktıların gerçekleşme düzeylerinin araştırıması beden eğitimi ve spor öğretim programının değerlendirilip geliştirilmesinde literatüre çok önemli katkılar sağlayacaktır. Edinilen araştırma bulguları ile diğer paydaşlara gerekli önlemleri alacak şekilde bilgilendirmesi önerilmektedir.

\section{Kaynakça}

Bloom, B.S., Hastings, J.T., \& Madaus, G.F. (1971). Insan nitelikleri ve okulda öğrenme. Ankara: Pegem Yayınları

Demirel, Ö. (2011). Kuramdan uygulamaya eğitimde program geliştirme. Ankara: Pegem Yayınları

Demirhan G. (1997). Beden eğitimi ve sporda öğretme-öğrenme etkinlikleri ve felsefe. Spor Bilimleri Dergisi, 8(1) 4-16.

Erdoğdu, M.. \& Öçalan, M. (2010). Illköğretim ikinci kademe beden eğitimi ders programının değerlendirilmesine ilişkin beden eğitimi öğretmenlerinin görüşleri. Spormetre Beden Eğitimi ve Spor Bilimleri Dergisi , 8 (4), 151-162 . DOl: 10.1501/Sporm_0000000190

Ertürk, S. (2015). Eğitimde Program Geliştirme. Ankara: Hacettepe Üniversitesi Basımevi.

Gülüm, V.. \& Bilir, P. (2011). Beden eğitimi öğretim programının uygulanabilme koşulları ile ilgili beden eğitimi öğretmenlerinin görüşleri. Spormetre, Beden Eğitimi ve Spor Bilimleri Dergisi, 9(2), 57-64.

Güven, B.. \& ileri, S. (2006). ilköğretim öğrencilerinin sosyal bilgiler dersinde oluşturdukları metaforlara ilişkin bir inceleme. XV. Ulusal Eğitim Bilimleri Kongresi. Bildiriler Kitabı. Muğla Üniversitesi

Karasar, N. (2015). Bilimsel araştırma yöntemi. Ankara: Nobel Yayıncılık.

Mamak, H. (2012). Illköğretim okullarında beden rğitimi ve spor derslerinin amaçlarına ulaşma düzeyini etkileyen faktörler. Selçuk Üniversitesi Beden Eğitimi ve Spor Bilim Dergisi, 14 (1), 109-115.

Milli Eğitim Bakanlığı [MEB] (2015). Millî Eğitim Bakanlığı öğretmen atama ve yer değiştirme yönetmeliği . Resmi gazete sayl: 29329.

Milli Eğitim Bakanlığı [MEB], (2013). Ortaokul beden eğitimi ve spor dersi program uygulama kılavuzu http://tegm.meb.gov.tr/www/ortaokul-beden-egitimi-ve-spor-dersi-program-uygulama-ki lavuzu-ortaokul-5-8-siniflar/icerik/156

Oliva, P. F. (1997) Program geliştirme. Ankara: Pegem Yayıncılık Eğitim Fakültesi.

Posner, J.G. (1992). Analyzing the curriculum. UK: Business Education Publishers Ltd.

Şirinkan, A. \& Gündoğdu, K. (2011). Öğretmenlerin ilköğretim beden eğitimi dersi öğretim programı ve plânlarına ilişkin algıları. Illköğretim Online, 10(1). 144-159.

Taşmektepligil, Y., Yılmaz, Ç., İmamoğlu, O,. \& Kılcıgil, E. (2006). ilköğretim okullarında beden eğitimi ders hedeflerinin gerçekleşme düzeyi. Spormetre Beden Eğitimi ve Spor Bilimleri Dergisi, 4(4), 139-147. 